\title{
Sexting and high sexual risk-taking behaviours among school youth in northern Ethiopia: estimating using prevalence ratio
}

\author{
Kidan Abrha, ${ }^{1}$ Alemayehu Worku, ${ }^{2}$ Wondwossen Lerebo, ${ }^{3}$ \\ Yemane Berhane ${ }^{4,5}$
}

'Department of Reproductive Health, Mekelle University, College of Health Sciences, School of Public Health, Tigray, Ethiopia

${ }^{2}$ Addis Ababa University School of Public Healtha, Addis Ababa, Ethiopia

${ }^{3}$ Department of Public Health, Mekelle University College of Health Sciences, Mekelle, Tigray, Ethiopia

${ }^{4}$ Department of Epidemiology, Addis Continental Institute of Public Health, Addis Ababa, Ethiopia

${ }^{5}$ Addis Ababa University College of Health Sciences, Addis Ababa, Ethiopia

\section{Correspondence to}

Mrs. Kidan Abrha, Department of Reproductive Health, Mekelle University, College of Health Sciences, School of Public Health, Tigray, Ethiopia; kidanabrha@ gmail.com

Received 16 February 2018 Revised 28 November 2018 Accepted 3 March 2019 Published Online First 27 April 2019

\section{A) Check for updates}

(C) Author(s) (or their employer(s)) 2019. No commercial re-use. See rights and permissions. Published by BMJ.

To cite: Abrha K, Worku A,

Lerebo W, et al. BMJ Sex

Reprod Health

2019:45:200-206.

\begin{abstract}
Background Increasing access to digital technology to young people in low-income settings has greatly influenced their porngraphy viewing and sexting, receiving and/or sending of sexual explicit materials via electronic devices. These change the sexual communication and behaviour of the young population. However, evidence to attest this change is not available in our setting. Thus, this study examined the relationship of high sexual risk-taking behaviour with sexting and pornography viewing among school youth in Ethiopia.
\end{abstract}

Methods A cross-sectional study was conducted from March to April 2015 by selecting school youth using a multistage sampling procedure. Data were collected using a pre-validated anonymous facilitator-guided self-administered questionnaire. Poisson regression was run to calculate adjusted prevalence ratio with its $95 \%$ confidence intervals. All differences were considered as significant for $p$ values $\leq 0.05$.

Results In total, 5924 questionnaires were distributed, and 5306 (89.57\%) school youth responded in full to questions related to outcome variables. Of these respondents, 1220 (22.99\%; 95\% Cl 19.45 to 26.96) were involved in high sexual risk-taking behaviour; 1769 (33.37\%; $95 \%$ Cl 30.52 to 36.35$)$ had experienced sexting and 2679 (50.26\%; $95 \% \mathrm{Cl}$ 46.92 to 53.61) were viewing pornography. The proportion of high sexual risk-taking behaviour was three-fold among pornography viewers (adjusted prevalence ratio (APR) 95\% Cl 3.02 (2.52 to 3.62)) and two-fold among sexters (APR $95 \% \mathrm{Cl} 2.48$ (1.88 to 3.27$)$ ) as compared with their counterparts.

Conclusions Exposure to sexually explicit materials via communication technology is associated with increased high sexual risk-taking behaviour among school youth in northern Ethiopia. Considering these emerged predictors

\section{Key messages}

Although sexting and pornography viewing are common, the evidence regarding their association with sexual risk-taking behaviours in low-income settings is scarce.

- The available information on the association between sexting and sexual risk-taking behaviours are often based on studies from high-income settings, which is contextually different from lowincome settings.

- This study indicates that sexting and pornography viewing are associated with sexual risk-taking behaviours in low-income contexts.

of sexual behaviours in our sexual education programmes, further research in this area is essential.

\section{INTRODUCTION}

Sexual risk-taking behaviour is an integral part of youth transition into adult life andrisk-taking propensity differs considerably in context. ${ }^{1}$ The increasing uptake of digital technologies has greatly influenced the sociocultural dynamics related to sexual norms and behaviours in every society. These days, school youth are highly exposed to sexually explicit materials through digital technologies. ${ }^{2}$ Although the use of digital tools per se is not in itself bad, its early facilitation and early sharing of sexual content has become a serious concern in societies that are not well prepared to prevent the potentially negative consequences. Youth involvement in sexting and viewing 
Table 1 Description and measurement of study variables included in the analysis

\begin{tabular}{|c|c|c|}
\hline Variable & Description & Measurement \\
\hline Sexual behaviour & $\begin{array}{l}\text { Participants who reported no condom use during their first and last episode of sexual intercourse and/or had } \\
\text { more than one sexual partner during their lifetime and/or had sex with non-regular partners were categorised } \\
\text { as being involved in high sexual risk-taking behaviour. } \\
\text { Participants who totally abstained from sexual intercourse or those who had had sexual intercourse with only } \\
\text { one sexual partner or with a regular partner, but reported using a condom during their first and last sexual } \\
\text { episode of intercourse were categorised as being involved in low sexual risk-taking behaviour. }{ }^{30}\end{array}$ & High, Low \\
\hline Contraceptive use & $\begin{array}{l}\text { Contraceptive use was measured using a question with 'Yes or No' response options: 'The last time you had } \\
\text { sexual intercourse, did you or your partner use any method of birth control, such as withdrawal, rhythm (safe } \\
\text { time), birth control pills, or any other method to prevent pregnancy?' } \\
\text { Those participants who respond 'Yes' were contraceptive users and those participants who respond 'No' were } \\
\text { non-users. }\end{array}$ & Yes, No \\
\hline Sexting & $\begin{array}{l}\text { 'Sexting' characteristics were assessed using the following two parameters with 'Yes or No' response } \\
\text { options. } \\
\text { 1. Have you ever received a (sexual nature) text and/or nude or semi-nude picture/image/photo/video of someone/yourself, } \\
\text { or a message on your cell phone/computer/internet? } \\
\text { 2. Have you ever sent a (sexual nature) text and/or nude or semi-nude picture/image/photo/video of someone/yourself, or } \\
\text { a message on your cell phone/computer/internet? } \\
\text { Those who responded 'Yes' at least for one of the above two questions were categorised as 'ever sexting'. } \\
\text { Sexting receivers were those who answered 'Yes' for question \#1 only. } \\
\text { Sexting senders were those who answered 'Yes' for question \#2 only. } \\
\text { NB. Each response could be complemented by those both sending and receiving. }\end{array}$ & Yes, No \\
\hline \multirow[t]{2}{*}{ Pornography watching } & $\begin{array}{l}\text { 'Pornography' was assessed by asking participants: } \\
\text { 'Have you ever watched magazine and/or films, images, videos, pictures that contain sexually explicit material } \\
\text { depicting naked or semi-naked bodies engaged in genital stimulation or sexual acts (pornography)?' } \\
\text { Those who answered 'Yes' were categorised as pornography viewers ever and those who did not were } \\
\text { categorised as non-viewers. }\end{array}$ & Yes, No \\
\hline & $\begin{array}{l}\text { For those who watched pornography, the question 'In the past } 6 \text { months, did you watch films, images, } \\
\text { videos, pictures that contain sexually explicit material depicting naked or semi-naked bodies engaged in } \\
\text { genital stimulation or sexual acts (pornography)?' was asked. } \\
\text { Those who answered 'Yes' were categorised as current pornography viewers and those who did not were } \\
\text { categorised as non-viewers currently. }\end{array}$ & Yes, No \\
\hline
\end{tabular}

pornography using smartphone applications is linked with problematic sexual behaviours. ${ }^{3}$

Sexual risk-taking behaviours, including having multiple sexual partners and inconsistent condom use among school youth, have been on the rise. In Ethiopia, there have been several studies that indicated an increasing proportion of youth have been involved in multiple sexual partnerships ${ }^{45}$ and that their condom use pattern was inconsistent. ${ }^{67}$

The published associations between sexting and sexual risk-taking behaviour among youth have been inconsistent. ${ }^{8}$ While some studies linked sexting with increased sexual activities and high sexual risk-taking behaviour, ${ }^{9-14}$ other studies reported no significant association between sexting and high sexual risk-taking behaviour. One of the reasons for the inconsistency was attributed to studies not using a uniform definition of sexual risk-taking behaviour. The definitions consider different items in different combinations: unprotected sex, number of sexual partners in the past year, and alcohol or drug use before sex ${ }^{9}$; the number of female or male sexual partners in the past 30 days and the number of episodes of unprotected sex ${ }^{15}$; the number of sexual partners, having experienced a sexually transmitted disease, having become unintentionally pregnant or having elected to abort a healthy pregnancy ${ }^{16}$; unprotected sex, number of partners, and substance use during sex. ${ }^{17}$ The published associations between pornography viewing and sexual risktaking behaviour have also been inconsistent for the same reason. ${ }^{18}$

The variations in the reported associations could also reflect contextual variations. In Ethiopia, the association between pornography, sexting and sexual risk-taking behaviour has not yet been studied in detail. $^{719}$ Consequenlty, the present study was conducted to examine the association of high sexual risk-taking behaviour with sexting and pornography viewing among school youth in northern Ethiopia.

\section{METHODS}

A school-based cross-sectional study was conducted in the Tigray Regional State in Northern Ethiopia. The region is administratively divided into South, East, West, Central, Southeast and Northwest zones, and Mekelle City Administration. The school system in the country is classified into four levels: primary first cycle (grades 1-4), primary second cycle (grades 5-8), secondary first cycle (grades 9-10/high school) and secondary second cycle (grades 11-12/preparatory school). Our study participants were drawn from high school and preparatory schools in the 2014-2015 academic year in selected public and private schools. Students from boarding, faith-based, prison, special 
Table 2 Sociodemographic characteristics of school youth, Ethiopia, 2015

\begin{tabular}{|c|c|c|}
\hline Category & $\begin{array}{l}\text { Frequency } \\
\text { (n) }\end{array}$ & $\begin{array}{l}\text { Percentage } \\
(\%)\end{array}$ \\
\hline \multicolumn{3}{|c|}{$\begin{array}{l}\text { Age (years) (median age } 17 \text { years) } \\
(n=5258)\end{array}$} \\
\hline $14-17$ & 3311 & 62.97 \\
\hline $18-24$ & 1947 & 37.03 \\
\hline \multicolumn{3}{|l|}{ Gender $(n=5296)$} \\
\hline Female & 2755 & 52.02 \\
\hline Male & 2541 & 47.98 \\
\hline \multicolumn{3}{|c|}{ Relationship status ( $n=5240$ ) } \\
\hline Single & 3576 & 68.24 \\
\hline In romantic relationship & 1536 & 29.31 \\
\hline Divorced & 128 & 2.45 \\
\hline \multicolumn{3}{|l|}{ Ethnicity $(n=5287)$} \\
\hline Tigrai & 5010 & 94.76 \\
\hline Amhara & 177 & 3.35 \\
\hline Other* & 100 & 1.89 \\
\hline \multicolumn{3}{|l|}{ Religion ( $n=5287$ ) } \\
\hline Orthodox Christian & 4834 & 91.43 \\
\hline Muslim & 365 & 6.90 \\
\hline Othert & 88 & 1.66 \\
\hline \multicolumn{3}{|l|}{ Living with $(n=5301)$} \\
\hline Both parents & 3217 & 60.69 \\
\hline One parent & 915 & 22.05 \\
\hline Other relatives & 1169 & 39.21 \\
\hline \multicolumn{3}{|l|}{ Grade level $(n=5296)$} \\
\hline Grade 9 & 1558 & 29.42 \\
\hline Grade 10 & 1680 & 31.72 \\
\hline Grade 11 & 1316 & 24.85 \\
\hline Grade 12 & 742 & 14.01 \\
\hline \multicolumn{3}{|l|}{ School ownership (n=5296) } \\
\hline Public & 4880 & 92.15 \\
\hline Private & 416 & 7.85 \\
\hline \multicolumn{3}{|l|}{ Residence ( $n=5296$ ) } \\
\hline Urban & 3809 & 71.92 \\
\hline Rural & 1487 & 28.08 \\
\hline \multicolumn{3}{|l|}{ Zone $(n=5296)$} \\
\hline Western & 1128 & 21.30 \\
\hline Southern & 1941 & 36.65 \\
\hline Mekelle & 2227 & 42.05 \\
\hline \multicolumn{3}{|c|}{ Father's occupation $(n=5279)$} \\
\hline Employed & 2336 & 44.25 \\
\hline Farmer & 2520 & 47.74 \\
\hline Daily labourer & 116 & 2.20 \\
\hline Other $\ddagger$ & 307 & 5.82 \\
\hline \multicolumn{3}{|c|}{ Mother's occupation $(n=5280)$} \\
\hline
\end{tabular}

Continued
Table 2 Continued

\begin{tabular}{lcl}
\hline Category & $\begin{array}{l}\text { Frequency } \\
\text { (n) }\end{array}$ & $\begin{array}{l}\text { Percentage } \\
(\%)\end{array}$ \\
\hline Employed & 1631 & 30.89 \\
\hline Housewife & 2761 & 52.29 \\
\hline Farmer & 695 & 13.16 \\
\hline Other $¥$ & 193 & 3.66 \\
\hline Father's education $(n=5284)$ & & \\
\hline No formal education & 2445 & 46.27 \\
\hline Primary & 966 & 18.28 \\
\hline Secondary and above & 1752 & 33.16 \\
\hline Other§ & 121 & 2.29 \\
\hline Mother's education $(n=5283)$. & & \\
\hline No formal education & 2781 & 52.64 \\
\hline Primary & 1110 & 21.01 \\
\hline Secondary and above & 1337 & 25.31 \\
\hline Other§ & 55 & 1.04 \\
\hline
\end{tabular}

*Benshangul, Agew, Oromo, Erob, Kunama and Afar.

†Protestant, Catholic and Adventist.

¥Not alive and migrated to Saudi.

$\S$ Not alive. The ' $n$ ' for each variable varies on acocunt of missing responses.

needs and international schools were not included in this study.

\section{Sample size}

This study is part of a larger school survey entitled 'The unforeseen challenges of technology on sexual risk-taking behaviour among school youth in Ethiopia', which involved a total of 5924 students. The sample size for the study was calculated using the double population proportion formula with the following assumptions: $27 \%$ sexting among females (P1) and 23\% among males (P2), ${ }^{20}$ design effect of 1.4 to account the clustering effect and $12 \%$ non-response.

A multistage cluster random sampling strategy was employed. In the first stage, 10 districts were selected from the total of 52 districts in the study area using a simple random sampling method. In the second stage, we selected 12 public and two private schools within each chosen district using proportional to number of Schools. In the third stage, 10-12 sections were randomly chosen from each randomly selected school. Finally, all students in the selected sections were invited to participate.

Data were gathered using a facilitator-guided, pre-validated, self-administered, anonymous questionnaire which was developed based on a review of the relevant literature. ${ }^{11} 1214$ The tool was first developed in English and then translated into the local language 'Tigrigna'; and it was also translated back into English by independent translators to check for item consistency. The major outcome of interest was sexual risk-taking behaviour and the independent variables 
Table 3 Sexual and technology use behaviour among school youth, Ethiopia, 2015

\begin{tabular}{|c|c|c|}
\hline Category & Frequency (n) & Percentage $(\%)(95 \% \mathrm{Cl})$ \\
\hline \multicolumn{3}{|l|}{$\begin{array}{l}\text { Involved in sexual risk-taking behaviour } \\
(n=5306)\end{array}$} \\
\hline High & 1220 & 22.9 (19.45 to 26.96$)$ \\
\hline Low & 4086 & 77.1 (73.04 to 80.55) \\
\hline \multicolumn{3}{|l|}{$\begin{array}{l}\text { Any contraceptive use during last sexual } \\
\text { episdoe }(n=1569)\end{array}$} \\
\hline Yes & 697 & 44.42 (41.95 to 46.92 ) \\
\hline No & 872 & 55.58 (53.08 to 58.05$)$ \\
\hline \multicolumn{3}{|l|}{ Technology use $(n=5314)$} \\
\hline Yes & 4784 & 90.03 (85.84 to 93.07$)$ \\
\hline No & 530 & 9.97 (6.93 to 14.16) \\
\hline \multicolumn{3}{|l|}{ Sexting $(n=5301)$} \\
\hline Yes & 1769 & 33.37 (30.52 to 36.35$)$ \\
\hline No & 3532 & 66.63 (63.65 to 69.48$)$ \\
\hline \multicolumn{3}{|l|}{ Receiver $(n=5301)$} \\
\hline Yes & 1699 & 32.05 (30.80 to 33.33$)$ \\
\hline No & 3602 & 67.95 (66.67 to 69.20$)$ \\
\hline \multicolumn{3}{|l|}{ Sender $(n=5301)$} \\
\hline Yes & 1372 & 25.88 (23.05 to 28.93$)$ \\
\hline No & 3929 & 74.12 (71.07 to 76.95$)$ \\
\hline \multicolumn{3}{|l|}{$\begin{array}{l}\text { Pornography ever viewing } \\
(n=5330)\end{array}$} \\
\hline Yes & 2679 & 50.26 (46.92 to 53.61$)$ \\
\hline No & 2651 & 49.74 (46.39 to 53.08 ) \\
\hline \multicolumn{3}{|c|}{ Current pornography viewing $(n=2679)$} \\
\hline Yes & 2179 & 81.34 (77.01 to 85.01$)$ \\
\hline No & 500 & 18.66 (14.99 to 22.99$)$ \\
\hline \multicolumn{3}{|l|}{ Mixed use $(n=2991)$} \\
\hline Pornography viewing only & 1222 & 23.05 (20.75 to 25.53$)$ \\
\hline Sexting only & 325 & 6.13 (4.71 to 7.95$)$ \\
\hline Pornography viewing and sexting & 1444 & 27.24 (24.76 to 29.87$)$ \\
\hline
\end{tabular}

were sexting and pornography viewing. The detail of measurement and description of the study variables included in the analysis are presented in table 1.

The questionnaire was piloted in schools which were not selected for the study. A test-retest reliability of measurement was determined to validate the tool by asking participants to complete the same questionnaire at 2-week interval. Point estimate and 95\% CI of kappa coefficient of each variable was determined. To estimate the CI of Cohen's kappa, an analytical method was used for dichotomous variables while a bootstrap was run for more than two levels of categorical variables. All variables showed statistically significant reliability with kappa coefficient ranging from 0.71 (95\% CI 0.47 to 0.95 ) to 1.00 (95\% CI 1.00 to 1.00 ).

Teachers and other school staff were not allowed in the classrooms where the questionnaire was being administered to protect students' privacy while completing the questionnaire. Participants were sparsely seated in the classroom to prevent sharing of responses. Participants were also asked to put completed questionnaires in a sealed box. University graduates were recruited and trained to serve as facilitators during data collection. The facilitators explained each question without interfering or looking at the responses. Facilitators were also responsible for ensuring that uniform data collection procedures were observed in all study schools. To avoid information contamination, data collection in schools within the same town was done at the same time and date.

\section{Statistical analysis}

A listwise deletion mechanism was used to handle missing data. The missing data in the Poisson regression model were due to item non-responses of the different explanatory variables included in the model. Only those questionnaires with complete data for all variables were included in the regression model.

To reduce the bias induced by multistage stratified cluster sample design and the unequal probability of selection of participants, complex survey data analysis was employed using STATA version 13 (StataCorp., College Station, TX, USA, 2013). ${ }^{21}$ To reduce bias resulting from variations in selection probabilities and non-response, the data were weighted.

Frequencies and prevalence with 95\% CI were reported for categorical variables. The median was computed for skewed continuous variables. Since the prevalence of the outcome was greater than $10 \%$, Poisson regression was used to estimate the adjusted prevalence ratio (APR) as the effect measure. ${ }^{22}$ Multicollinearity was checked using variance inflation factors (VIF) and there was no variable with VIF $>2$ in the final model. Variables' prevalence ratio with a $p$ value $\leq 0.1$ in the bivariate was entered into a multivariable model. All differences were considered as significant for $\mathrm{p}$ values $\leq 0.05$; APR and its $95 \%$ CIs were reported.

\section{Ethics}

Ethical approval was obtained from the Health Research Ethical Review Committee of Mekelle University. Permission to conduct the study in the selected schools was obtained from education offices and the school principals. Written informed consent was obtained from each study participant. For those participants younger than 18 years of age, their assent and their parents'/legal guardians' informed consent was taken. Confidentiality was assured and each student was given the opportunity to decide whether or not to participate in the study. At the end of the data collection sessions students were informed about how to access helplines in case they required help concerning matters related to the study topic.

\section{Patient and public involvement statement}

All study participants were apparently healthy school youth. No patients per se were included in the study. 
Table 4 Factors contributing to sexual risk-taking behaviour among school youth, Ethiopia, 2015

\begin{tabular}{|c|c|c|c|c|}
\hline \multirow[b]{2}{*}{ Category } & \multicolumn{2}{|c|}{ Sexual risk-taking behaviour ( $\mathrm{n}$ ) } & \multicolumn{2}{|c|}{ Prevalence ratio $(95 \% \mathrm{Cl})$} \\
\hline & High & Low & Crude & Adjusted \\
\hline \multicolumn{5}{|l|}{ Gender } \\
\hline Male & 723 & 1811 & $1.58(1.25$ to 2.00$)$ & $1.00(0.80$ to 1.24$)$ \\
\hline Female & 495 & 2243 & 1 & 1 \\
\hline \multicolumn{5}{|l|}{ Age (years) } \\
\hline $14-17$ & 610 & 2694 & 1 & 1 \\
\hline $18-24$ & 602 & 1339 & $1.68(1.45$ to 1.95$)$ & $1.20(1.02$ to 1.42$) *$ \\
\hline \multicolumn{5}{|l|}{ Zone } \\
\hline West & 199 & 927 & 1 & 1 \\
\hline South & 498 & 1470 & 1.43 (0.99 to 2.07$)$ & $1.23(0.91$ to 1.66$)$ \\
\hline Mekelle & 523 & 1689 & 1.34 (0.85 to 2.11$)$ & 1.38 (0.98 to 1.94$)$ \\
\hline \multicolumn{5}{|l|}{ Ethnicity } \\
\hline Tigrai & 1132 & 3878 & 1 & 1 \\
\hline Amhara & 39 & 139 & 0.97 (0.69 to 1.37$)$ & 1.00 (0.84 to 1.19$)$ \\
\hline Othert & 46 & 56 & 2.00 (1.52 to 2.62$)$ & 1.57 (1.24 to 1.97$)$ \\
\hline \multicolumn{5}{|l|}{ Religion } \\
\hline Orthodox Christian & 1098 & 3739 & 1 & 1 \\
\hline Muslim & 91 & 274 & 1.10 (0.88 to 1.37$)$ & 0.99 (0.83 to 1.18$)$ \\
\hline Other $\ddagger$ & 28 & 59 & 1.42 (0.98 to 2.06$)$ & 1.13 (0.70 to 1.84$)$ \\
\hline \multicolumn{5}{|l|}{ School ownership } \\
\hline Government & 1180 & 3716 & 2.47 (1.80 to 3.39$)$ & $2.48(2.15 \text { to } 2.87)^{*}$ \\
\hline Private & 40 & 370 & 1 & 1 \\
\hline \multicolumn{5}{|l|}{ Living with } \\
\hline Both parents & 679 & 2529 & 1 & 1 \\
\hline One parent & 219 & 687 & 1.14 (0.89 to 1.46$)$ & 1.07 (0.89 to 1.28$)$ \\
\hline Relatives & 318 & 845 & $1.29(0.98$ to 1.70$)$ & 1.14 (0.97 to 134) \\
\hline \multicolumn{5}{|l|}{ Technology use } \\
\hline Yes & 1149 & 3615 & $1.87(1.30$ to 2.70$)$ & 0.88 (0.57 to 1.35$)$ \\
\hline No & 68 & 459 & 1 & 1 \\
\hline \multicolumn{5}{|l|}{ Sexting } \\
\hline Yes & 818 & 946 & 4.08 (3.06 to 5.47$)$ & $2.48(1.88 \text { to } 3.27)^{*}$ \\
\hline No & 400 & 3116 & 1 & \\
\hline \multicolumn{5}{|l|}{ Pornography viewing } \\
\hline Yes & 1010 & 1656 & 4.76 (3.61 to 6.28$)$ & $3.02(2.52 \text { to } 3.62)^{*}$ \\
\hline No & 210 & 2430 & 1 & 1 \\
\hline
\end{tabular}

A detailed explanation of the aim of the study and the benefits of the outcome of the study were given to participants prior to administering the questionnaire. There were a series of discussions with teachers and other stakeholders about the aim of the study and the data collection procedures. The authors aim to disseminate the study findings in the annual research review of Mekelle University, and additionally by means of conference presentations, community conversations and via local media. The study findings will also be submitted to the Ethiopia Federal Ministry of
Education and Health and to Regional Education and Health Bureau as well as theschools.

\section{RESULTS}

\section{Sociodemographic characteristics}

A total of 5924 questionnaires were distributed, of which 5306 (89.57\%) respondents answered in full the outcome variable questions (which were used to determine the sexual risk-taking behaviour). The median age of participants was 17 years; 2730 (52.02\%) of 
respondents were female and 4914 (92.2\%) were students from public schools (table 2).

\section{Description of sexual, sexting and pornography behaviours}

Overall, 1220 (22.99\%; 95\%CI 19.45 to 26.96) respondents were involved in high sexual risk-taking behaviour; 1769 (33.37\%; 95\% CI 30.52 to 36.35) in sexting, and 2679 (50.26\%; 95\% CI 46.92 to 53.61) in viewing pornography (table 3 ).

\section{Variables associated with high sexual risk-taking behaviour}

Poisson regression analysis showed that the proportion of high sexual risk-taking behaviour was three times higher (APR 3.02; 95\% CI 2.52 to 3.62) among pornography viewers and 2.5 times higher (APR 2.48; $95 \%$ CI 1.88 to 3.27 ) among sexters than their counterparts (table 4).

\section{DISCUSSION}

This study showed that $22.99 \%$ of the participants were involved in high sexual risk-taking behaviours which was fairly strongly associated with sexting and pornography viewing. The high sexual risk-taking behaviours could expose the youth to sexually transmitted infections and unintended pregnancy.

The relationship between high sexual risk-taking behaviour and sexting observed in this study was consistent with some previous studies. ${ }^{10} 1214202324$ Young adolescents who are in involved in sexting before attaining full cognitive maturity about their sexual behaviours could be exposed to high sexual risk-taking behaviours. ${ }^{3}$ Sexting could also encourage having sex that defies social norms regarding sexual activities at a younger age and sexual experimentation that in the long run might harm young people's sexual and reproductive health. ${ }^{20}$

In its complexity, human behaviour is affected and conditioned by a large number of contributing and alternative factors. According to the theory of planned behaviour model, ${ }^{25}$ these factors might have a bearing on the individual's attitudes, subjective norms and perceived behaviour control on the intentions to high sexual risk-taking behaviour among sexters. The sexual behaviour of those individuals who received texts of a sexual nature voluntarily may differ from those who did not; unfortunately we did not include this question in the present study due to the limited time available for administering the questionnaire which forced us to reduce the number of questions. We strongly encourage future research to consider including questions on voluntariness.

In our study, watching pornography was associated with high sexual risk-taking behaviour which is consistent with previous school-based surveys. ${ }^{23} 2627$ Youth who watch pornography would be curious to try out and indulge in sexual acts that could result in high sexual risk-taking behaviour. ${ }^{28}$ This indicates that sexual health educators, reproductive health experts and clinicians need to include safe digital technology utilisation in public healthcare interventions.

The majority of the study participants were current pornography users. This might indicate that viewing pornography at some time in life may be difficult to stop viewing which contributes to addiction and highrisk behaviour.

This study also showed that students attending government schools were more likely to be involved in high sexual risk-taking behaviour than those attending private schools. This might be related to the difference in access to information regarding risk sexual behaviour and the level of parental control.

Our study tried to generate a valid estimate by minimising information contamination; data collection in schools within the same town was done on the same day and time. Although contamination due to sharing of information via digital technology is a possibility, we do not believe it is likely to be a major source of bias since high school students are unlikely to have friends outside their home town. This study employed a large sample size and a probability sampling method, and considering that the school system is more or less the same throughout Ethiopia, and access to digital technology is comparable, the findings of this study are fairly generalisable to low-income settings throughout the country. Social desirability bias can also result in either under- or over-reporting of sexually related activities depending on the prevailing social norms. For example, girls tend to under-report and boys tend to over-report sexual activities in Ethiopia. ${ }^{29}$ To minimise social desirability bias, the interview was self-administered and maximum efforts were made to ensure privacy and confidentiality. Thus, the reported estimates and the relationships are unlikely to have been heavily influenced by social desirability bias. To the best of our knowledge, this is the first large-scale study to employ a comprehensive definition of sexting in Ethiopia. However, because of the nature of the study design, it is not possible to establish the temporality of the observed associations.

\section{CONCLUSIONS}

In conclusion, high sexual risk-taking behaviour was strongly associated with sexting and pornography viewing practices. This implies the need for immediate action to introduce appropriate interventions to protect the immediate and long-term sexual and reproductive health of students.

Acknowledgements The authors gratefully acknowledge Mekelle University for financial support and Addis Continental Institute of Public Health for the overall material and technical support. They are also grateful to the Tigray Educational Bureau and the school principals for their overall facilitation of the field work. They thank study participants for their 
willingness to participate in the study, and data collection facilitators and supervisors for their diligent work.

Contributor KA, AW, WL and YB were responsible for the conception and design of the study. The acquisition, analysis, interpretation of data and the initial drafting of the manuscript were done by KA. AW supervised and contributed to the analysis and interpretation of the data and he also revised the draft manuscript. WL contributed to the analysis and interpretation of the data. YB revised the manuscript critically for important intellectual content. KA, AW, WL and YB have read and approved the final manuscript prior to publication.

Funding This study is funded by Mekelle University.

Competing interests None declared.

Patient consent for publication Not required.

Provenance and peer review Not commissioned; externally peer reviewed.

\section{REFERENCES}

1 Yi S, Poudel KC, Yasuoka J, et al. Role of risk and protective factors in risky sexual behavior among high school students in Cambodia. BMC Public Health 2010;10:477.

2 Habesha T, Aderaw Z, Lakew S. Assessment of exposure to sexually explicit materials and factors associated with exposure among preparatory school youths in Hawassa City, Southern Ethiopia: a cross-sectional institution based survey. Reprod Health 2015;12:1-12.

3 Tanton C, Jones KG, Macdowall W, et al. Patterns and trends in sources of information about sex among young people in Britain: evidence from three national surveys of sexual attitudes and lifestyles. BMJ Open 2015;5:e007834.

4 Seme A, Wirtu D. Premarital sexual practice among school adolescents in Nekemte Town, East Wollega. Ethiop J Health Dev 2008;22:167-73.

5 Fentahun N, Mamo A. Risky sexual behaviors and associated factors among male and female students in Jimma Zone preparatory schools, South West Ethiopia: comparative study. Ethiop J Health Sci 2014;24:59-68.

6 Gebremichael H, Tebeje W, Alemayehu M, et al. Magnitude and predictors of self-reported sexually transmitted infections among school youths in Bahir-Dar. Northwest Ethiopia Ethiop Med J 2017;55:129-37.

7 Bogale A, Seme A. Premarital sexual practices and its predictors among in-school youths of Shendi town, west Gojjam zone, North Western Ethiopia. Reprod Health 2014;11:1-9.

8 Klettke B, Hallford DJ, Mellor DJ. Sexting prevalence and correlates: a systematic literature review. Clin Psychol Rev 2014;34:44-53.

9 Temple JR, Choi H. Longitudinal association between teen sexting and sexual behavior. Pediatrics 2014;134:e1287-92.

10 Ybarra ML, Mitchell KJ. "Sexting" and its relation to sexual activity and sexual risk behavior in a national survey of adolescents. J Adolesc Health 2014;55:757-64.

11 Rice E, Gibbs J, Winetrobe H, et al. Sexting and sexual behavior among middle school students. Pediatrics 2014;134:e21-8.

12 Dake JA, Price JH, Maziarz L, et al. Prevalence and correlates of sexting behavior in adolescents. Am J Sex Educ 2012;7:1-15.

13 Benotsch EG, Snipes DJ, Martin AM, et al. Sexting, substance use, and sexual risk behavior in young adults. J Adolesc Health 2013;52:307-13.
14 Temple JR, Paul JA, van den Berg P, et al. Teen sexting and its association with sexual behaviors. Arch Pediatr Adolesc Med 2012;166:828-33.

15 Gordon-Messer D, Bauermeister JA, Grodzinski A, et al. Sexting among young adults. J Adolesc Health 2013;52:301-6.

16 Ferguson CJ. Sexting behaviors among young Hispanic women: incidence and association with other high-risk sexual behaviors. Psychiatr Q 2011;82:239-43.

17 Davis MJ, Powell A, Gordon D, et al. I want your sext: sexting and sexual risk in emerging adult minority men. AIDS Educ Prev 2016;28:138-52.

18 Harkness EL, Mullan B, Mullan BM, et al. Association between pornography use and sexual risk behaviors in adult consumers: a systematic review. Cyberpsychol Behav Soc Netw 2015;18:59-71.

19 Mulugeta Y, Berhane Y. Factors associated with pre-marital sexual debut among unmarried high school female students in Bahir Dar Town, Ethiopia: cross- sectional study. Reprod Health 2014;11:40.

20 Patrick K, Heywood W, Pitts MK, et al. Demographic and behavioural correlates of six sexting behaviours among Australian secondary school students. Sex Health 2015;12:480-7.

21 Stapleton LM. Analysis of data from complex surveys. International handbook of survey methodology. New York: Taylor and Francis Group, 2008:342-69.

22 Barros AJ, Hirakata VN. Alternatives for logistic regression in cross-sectional studies: an empirical comparison of models that directly estimate the prevalence ratio. BMC Med Res Methodol 2003;3:1-13.

23 Stanley N, Barter C, Wood M, et al. Pornography, sexual coercion and abuse and sexting in young people's intimate relationships: a European study. J Interpers Violence 2018;33:2919-44.

24 Rice E, Rhoades H, Winetrobe $\mathrm{H}$, et al. Sexually explicit cell phone messaging associated with sexual risk among adolescents. Pediatrics 2012;130:667-73.

25 Espada JP, Morales A, Guillén-Riquelme A, et al. Predicting condom use in adolescents: a test of three socio-cognitive models using a structural equation modeling approach. BMC Public Health 2016;16:1-10.

26 Shek DT, Ma CM. Consumption of pornographic materials among Hong Kong early adolescents: a replication. ScientificWorldJournal 2012;2012:1-8.

27 Kheswa JG, Notole M. The impact of pornography on adolescent males' sexual behaviour in the eastern Cape, South Africa. A Qualitative Study. Mediterr J Soc Sci 2014;5:2831-40.

28 Rothman EF, Adhia A. Adolescent pornography use and dating violence among a sample of primarily black and Hispanic, urban-residing, underage youth. Behav Sci 2015;6:1-12.

29 Versnel M, Berhane Y, Wendte JF. Sexuality and contraception among never married high school students in Butajira, Ethiopia. Ethiop Med J 2002;40:41-51.

30 Wu Y, Burns JJ, Stanton BF, et al. Influence of prior sexual risk experience on response to intervention targeting multiple risk behaviors among adolescents. $J$ Adolesc Health 2005;36:56-63. 